\title{
Arbor
}

\section{La transición democrática en el periodismo político de Francisco Umbral}

\author{
Carlos X. Ardavín
}

Arbor CLXIII, 642 (Junio 1999), 179-185 pp.

El presente artículo representa un estudio del articulismo político de Francisco Umbral referido al tema de la transición democrática, y asume como tesis que el citado articulismo articula una visión irónica y escéptica de dicho proceso. Para ello, se analizan una serie de recopilaciones periodísticas que demuestran el alto grado de visión política de Umbral y su sostenida voluntad de reflexión en torno al hecho más importante de la reciente historia política de España.

La temática transicional es una de las principales constantes en la ficción y la obra periodística de Francisco Umbral. Con frecuencia el comentario crítico de la transición elaborado a través de sus artículos se duplica a nivel ficcional en novelas y narraciones que combinan el lenguaje de la imaginación con el de la historia. Inmerso en el orden imaginativo, el escritor transmuta el pasado empírico con su repertorio de fechas y datos específicos en propiedad estética, mediante la reescritura de la historia y la introducción de hechos y personajes creados por su inventiva. En este sentido, Umbral ha mantenido que los escritores registran la historia con más precisión y encanto que los mismos historiadores, y como ejemplos de esto menciona a Ramón del Valle-Inclán, Pío Baroja y Benito Pérez Galdós (Guía irracional de España 72). Si en las novelas de los citados autores puede leerse 
la España decimonónica, en las que Umbral ha dedicado a la transición política queda narrada la nueva España postfranquista, sus inicios y su accidentada trayectoria.

En Umbral puede hablarse de un reiterado compromiso de reconstrucción de la memoria transicional frente a las versiones complacientes y monológicas fabricadas y puestas en circulación por los historiadores y políticos. Dicho compromiso se ha concretado hasta ahora en cuatro novelas y en un ingente número de artículos, crónicas y ensayos ${ }^{1}$.

Incluso en la parcela más íntima de su obra, sus diarios de escritor, la transición política ha sido objeto de su atención, tematizándose e invadiendo el espacio autobiográfico ${ }^{2}$. La historia y sus avatares políticos aparecen ligados a la propia vida y memoria del escritor, conformando un vínculo indisoluble con su escritura. En última instancia, meditar sobre la transición democrática es para Umbral un ejercicio de autoconocimiento, una suerte de indagación personal y colectiva a través de la cual se registran sucesos intensamente vividos y cronificados. Ya sea en crónicas noveladas que intentan preservar la efervescencia primigenia de los acontecimientos, escritas al calor de los mismos; ya sea en rememoraciones literarias provistas de la suficiente perspectiva histórica, lo cierto es que Francisco Umbral ha hecho de la transición política un tiempo a la vez real e imaginario.

La novelización umbraliana de la transición democrática tiene un fundamento ideológico expresado sobre todo en el ámbito periodístico y a través de algunos ensayos, cuyo análisis revela una visión escéptica de la transición, apenas atemperada por escasas ráfagas de optimismo. El periodismo tardofranquista y transicional de Francisco Umbral tiene como ilustre antecedente el articulismo político y de costumbres de Mariano José de Larra, escritor biografiado por Umbral en su primer libro $^{3}$. De Fígaro, el novelista madrileño toma la noción de crónica moderna, como él mismo admite ${ }^{4}$. Pero la afinidad entre Larra y Umbral no sólo es literaria sino en sumo grado ideológica: el temprano y sostenido escepticismo transicional de Umbral remeda el paradigma de crítica histórica presente en los artículos políticos y costumbristas de Larra. Con respecto a este último punto, el propio Umbral ha manifestado su afinidad con el "costumbrismo crítico" larraniano (Heymann 23-24). Para Francisco Umbral, Larra se inscribe, junto con Quevedo y ValleInclán (exponentes de lo que denomina la "raza híspida"), dentro de una "línea de pensamiento crítico español" cuya finalidad primordial consiste en "despertar a este país de su autosatisfacción indecente" (Valle Inclán 7-8). Tal es la orientación que subyace en los articulos 
y ensayos de interpretación en torno a la transición política que Umbral fue publicando desde 1973-1974 hasta mediados los noventa.

Puede afirmarse sin temor a equívocos que Umbral es uno de los más tempranos y lúcidos comentadores de la transición política, dejando constancia de sus opiniones en pleno tardofranquismo, cuando aún la democracia era sólo un proyecto ambiguo en las mentes de los aperturistas y una revolución utópica en los círculos antifranquistas. Prueba de la relajación de la represión cultural que se verificó en España a partir de los setenta es el hecho de que Umbral reuniera en 1974 unas Crónicas antiparlamentarias, publicadas con anterioridad en la prensa nacional y en las que trataba sin tapujos la problemática política y social de la moribunda dictadura franquista. Se trata de crónicas que, sin excluir el tema político, recogen el sentir de una sociedad en plena metamorfosis mental que el cronista percibe en la cotidianidad y la intrahistoria. No obstante esto, se deja constancia del radical inconformismo del escritor ante tales cambios, a todas luces insatisfactorios e insuficientes. Un examen minucioso del articulismo umbraliano de la primera mitad del 70 demuestra con qué puntualidad y elocuencia el periodista madrileño fue inventariando el desarrollo de la transición democrática paso a paso y desde múltiples perspectivas. Gran parte de esta labor es recogida en 1975, año en que Umbral publica tres libros periodísticos: Suspiros de España, Diario de un español cansado y España cañí. En ellos se prefigura una visión irónica de la democracia española antes de que ésta comenzara su andadura. La incredulidad democrática discernible en estos artículos podría adjudicarse al hondo pesimismo que, de acuerdo con Joaquín Marco, subyace en el conjunto de la obra umbraliana ("La rosa y el látigo" 11), y que sustenta tanto su parcela estrictamente periodística como la más cercana a la ficción ${ }^{5}$. Esta visión irónica no hace más que subrayar uno de los temas predilectos de Umbral con respecto a la transición: la dificultad de la invención de la democracia, su complejo asentamiento en la conciencia del pueblo español; dificultad que tiene su origen primordial en el inveterado guerracivilismo de la sociedad hispánica.

Con la llegada de la democracia, el periodismo político de Umbral se acrecienta y en 1976 publica tres recopilaciones de artículos y crónicas ${ }^{6}$. En ellas la incredulidad democrática del escritor se refrena mediante una férrea voluntad por contribuir a crear una democracia real y auténtica, fundamentada en la libertad de expresión y pensamiento. La lucha por la palabra libre será la tónica de estos artículos que buscan anular la longeva censura impuesta a la ciudadanía, que 
en los primeros momentos de la transición aún permanecía vigente. En este estadio temprano de la transición política, Umbral parece tomar conciencia de la fragilidad de la situación nacional y asume una actitud más participativa que testimonial; de espectador irónico de la transición se convierte en su convencido defensor: «Es el momento de dar la batalla democrática en la vida española, recordando, según dice mi amigo y compañero Manuel Vicent, que la libertad y la democracia nadie las regala, sino que hay que conquistarlas, a veces muy duramente (Crónicas post-franquistas 10). Finalmente, en Los políticos la democracia se metaforiza en una "bicicleta ideológica" que se quiere individual e intransferible, en la que el ciudadano pueda recorrer a su antojo el espacio de la libertad (180). No obstante la tonalidad optimista y vitalista que se percibe en estos libros periodísticos, la ironía y el pesimismo, elementos inalienables de la concepcion histórica umbraliana, no cesan de funcionar como correctores de la primera.

En una entrevista con Pilar Trenas en agosto de 1980, Francisco Umbral hace una evaluación de la transición política transcurridos cinco años desde su comienzo institucional, en la que sostiene que ésta ha inaugurado un clima de libertad muy positivo y fructífero para la creación literaria, pero no porque se haya ellminado la censura, sino porque el escritor se ha despojado de su mala conciencia antifranquista que le obligaba a una literatura comprometida y socialrealista. En esta misma entrevista, Umbral afirma que la transición ha significado para él una especie de "salvación en la imaginación", y que en ella la escritura es una cuestión de talento y no de testimonio oposicional. Esta salvación imaginativa tiene como una de sus motivaciones lo que Umbral califica de segunda juventud (9). La transición como segunda juventud puede considerarse una inflexión en el escepticismo democrático de Umbral, y como tal, un estado de breve duración.

La euforia y el entusiasmo que se desprenden de las declaraciones de 1980 parecen difuminarse a medida que transcurren los ochenta. Es en la primera mitad de esta década cuando Umbral publica dos libros fundamentales para entender su ficcionalización de la transición política: Los ángeles custodios (1981) y Spleen de Madrid/2 (1982). Ambos pueden considerarse como intertextos de $A$ la sombra de las muchachas rojas (1981). Entre esta novela y los dos libros citados, los puntos de contacto y el trasvase de materiales son numerosos, siendo la primera una transcripción en el plano ficcional de las preocupaciones e ideas expresadas en los segundos. Entre los puntos de contacto que con mayor insistencia se repiten está la anticipación cultural de la transición 
política diez años antes de que expirara la dictadura franquista, y que Umbral cifra en dos hechos literarios: Ia publicación de Arde el mar de Pere Gimferrer y la irrupción del ensayismo de Fernando Savater, los cuales demostraban que la belleza estética y la indiferencia hacia el tardofranquismo tenían un efecto subversivo más poderoso que el trasnochado y manido socialrealismo (Los ángeles custodios 150). Tanto Los ángeles custodios como Spleen de Madrid/2 retoman el escepticismo democrático de Umbral; sobre todo el segundo, escrito tras el golpe del 23-F.

El sentido de frustración que Umbral experimenta con la transición política puede insertarse en el contexto de las renuncias y concesiones ideológicas que la izquierda española, especialmente el PCE, se vio en la necesidad de realizar durante el decurso transicional. La ansiada ruptura democrática, que por largo tiempo guió la estrategia de lucha de los antifranquistas históricos, se desvaneció frente a la estrategia reformadora del suarismo y la monarquía juancarlista. De ahí que en 1984 Umbral declare que «ibamos a hacer una revolución y sólo estamos haciendo una transición" (Trilogía de Madríd 324). Tal manifestación encaja dentro de la aguda desilusión que vivió la progresía española y los intelectuales de izquierda a medida que se concretaba la transición política, que no cumplió, evidentemente, con sus expectativas históricas.

Se suele afirmar que el paso del tiempo embellece la realidad histórica y conturba la memoria. No sucede esto con respecto a la visión umbraliana de la transición. Llegados los noventa, ésta sigue conservando el mismo grado de ironía y crítica, ahora escoradas un tanto al nihilismo. Sorprende que transcurrido un cuarto de siglo desde la publicación de sus primeros artículos políticos dedicados a la transición democrática, Umbral no haya modificado sustancialmente su concepción escéptica de la misma; por el contrario, ésta se ha afianzado con el paso de los años. La posibilidad de una "nueva edad de plata" cultural alentada por la restauración democrática que Umbral apuntaba en España como invento (49), queda reducida en los noventa a la implantación de una cultura festiva, postmoderna y superficial (La década roja 215). La ilusión de una transformación radical de la mentalidad y estructuras de España a partir de la transición política se ha visto frustrada, y en su lugar se ha producido un proceso de tipo cosmético ?. De ahí que en 1995, al ser cuestionado por $A B C$ acerca de la transición, Umbral la haya definido en términos lacónicos y lapidarios como «una cosa que está por hacer» («Sesenta veces Umbral»16), significando así el fracaso del proceso democrático. 


\section{Notas}

1 Las cuatro novelas son, por orden cronológico, A la sombra de las muchachas rojas. Crónicas marcianas de la transición (1981), Sinfonía borbónica (1987), Y Tierno Galván ascendió a los cielos (1990) y Memorias borbónicas (1992). Entre las recopilaciones de artículos cabe citar Suspiros de España (1975), Iba yo a comprar el pan (1976) y Spleen de Madrid/2 (1982); entre los ensayos destacan España como invento (1984) y La década roja (1993).

2 Dos de los títulos más ampliamente conocidos son Diario de un escriror burgués (1979) y Los ángeles custodios (1981).

3 Larra, anatomía de un dandy (1965).

4 Ver el prólogo a Mariano José de Larra: Antología fugaz, en donde Umbral se identifica con el citado autor en virtud del tipo de crónica cultivada por él: rabiosamente personal y autobiográfica, y de extensión breve (25). La impronta de Larra en la obra de Umbral ha sido ampliamente señalada por los críticos. En este sentido, Andrés Amorós apunta que muchos consideran a Umbral como "el gran costumbrista de nuestros días" (73).

5 El propio Joaquín Marco ha señalado que el radical pesimismo de la obra umbraliana se resuelve en un "esteticismo redentor" (Memorias borbónicas" 7).

6 Iba yo a comprar el pan..., Los políticos y Crónicas post-franquistas.

7 Eduardo Subirats entiende la frustración ante la transición democrática dentro del contexto general del fracaso de la modernización, cuyos orígenes están en la precaria reforma del pensamiento durante la Ilustración española. Para Subirats la transición política implantó una apariencia de modernización más que un proceso auténtico de cambios ("Postmoderna modernidad: La España de los felices ochenta" 11).

\section{Bibliografía}

Amorós, Andrés. «Perspectivas críticas: horizontes infinitos. Para leer a Francisco Umbral, Mortaly rosa". Anales de la novela de posguerra. Vol. 2 (1977): 73-79.

Heymann, Jochen y Montserrat Mulor-Heymann. Retratos de escritorio. Entrevistas a autores españoles. Frankfurt am Main: Vervuert Verlag, 1991.

MARCO, JoAQufN. "Memorias borbónicas". ABC Literario 53 (6 nov. 1992): 7.

- "La rosa y el látigo". ABC Literario 159 (18 noviembre 1994): 11.

Subirats, Eduardo. La ilustración insuficiente. Madrid: Taurus, 1981.

- "Postmoderna modernidad: La España de los felices ochenta". Quimera 145 (marzo, 1996): 11-18.

Trenas, PIlar. "Entrevista. Con Los helechos, contra Los helechos". ABC (7 agosto 1980): $8-9$.

Umbral, Francisco. Larra. Anatomía de un dandy. Madrid: Alfaguara, 1965.

- Valle-Inclán. Madrid: Unión Editorial, 1968.

- Crónicas antiparlamentarias. Madrid: Ediciones Júcar, 1974.

- España cañi. Madrid: Plaza y Janés, 1975.

- Suspiros de España. Madrid: Ediciones Felmar, 1975.

- Diario de un español cansado. Barcelona: Destino, 1975.

- Los políticos. Madrid: Sedmay Ediciones, 1976. 


\section{La transición democrática en el periodismo político...}

- Crónicas post-franquistas. Madrid: A.Q. Ediciones, 1976.

- Iba yo a comprar el pan... Madrid: Sedmay Ediciones, 1976.

- Diario de un escritor burgués. Barcelona: Destino, 1979.

- Mariano José de Larra: Antología fugaz. Madrid: Alianza Editorial, 1979.

- A la sombra de las muchachas rojas. Crónicas marcianas de la transición. Madrid: Ediciones Cátedra, 1981.

- Los ángeles custodios. Barcelona: Destino, 1981.

- Spleen de Madrid/2. Barcelona: Destino, 1982.

- España como invento. Madrid: Ediciones Libertarias, 1984.

- Sinfonía borbónica. Barcelona: Destino, 1987.

- Guía irracional de España. Madrid: Arnao Ediciones, 1989.

- Y Tierno ascendió a los cielos. Barcelona: Seix Barral, 1990.

- Memorias borbónicas. Barcelona: Planeta, 1992.

- La década roja. Barcelona: Planeta, 1993.

- "Sesenta veces Umbral». ABC Cultural 184 (12-05-95): 16-17.

- Trilogía de Madrid. Barcelona: Planeta, 1996. 